\title{
Appraisal of Teachers' Index in primary and upper primary level: a Geospatial Analysis
}

\author{
Gouri Sankar Bhunia ${ }^{1}$, Pravat Kumar Shit ${ }^{2}$ \\ ${ }^{I}$ Senior Research Fellow (ICMR), Rajendra Memorial Research Institutes of Medical Sciences \\ (ICMR),Agamkuan, Patna-800007, Bihar, India. \\ ${ }^{2}$ Department of Geography \& Environment Management, Vidyasagar University, Medinipur.721102, West \\ Bengal, India.
}

\begin{abstract}
The present study analyses the teaching-learning environment for educational development of Paschim Medinipur district, considered as an important segment of social science research. District Information System for Education (DISE) for the year 2009 - 2010 was used for the present study which has been recorded from the 4,671 primary schools and 751 upper primary schools across the entire district. To develop a teacher index map pupil-teacher ratio, pupil-female teacher ratio, school-student ratio, schoolteacher ratio, classroom-student ratio, school-classroom ratio, and the percent of trained teacher was used as influencing parameters. A relational database was generated on the GIS platform and a generalized score was given to each parameter to categorize the block to measures the educational development status. Result of the study showed average pupil-teacher ratio was 29.31percent in the district, while the district had 24.43 percent female teachers at primary level and 29.42 percent at upper primary level. Results also illustrated that schoolteacher ratio (rho - 0.52), school-student ratio (rho - 0.44), school-classroom ratio (rho - 0.60) showed positive and significant relationship with the average per cent of passed student. However, blocks of the eastern part of the district are attaining highest facility compare to the western part at both the primary and upper primary level. These efforts on the part of pioneering teachers are to be acclaimed-they have helped to demonstrate that powerful analytic tools can be made accessible to students.
\end{abstract}

Keywords: Teacher index, GIS, Index overlay, Educational development

\section{Introduction}

Educational system in India, particularly at primary and upper primary level, is characterised by underprivileged quality (Desai and Kulkarni, 2008). Reforms in school education are pivotal for creating an edifice on which a knowledge society can be structured. While India has witnessed significant progress in school education, and the goal of universal admittance to elementary education has yet not been achieved. There are also ample discrepancies in admission to school education between states, rural and urban areas, gender as well as dissimilar economic classes (NRIC, 2006; Ward, 2007). Moreover, issues of superiority such as teacher training, curriculum, pedagogy, school infrastructure and learning outcomes should have addressed on an instantaneous root (Alexander, 2008). There is also an urgent need to increase the resource allocation to school education.

One of the dominant factor contributing to low learning apart from social, economic and numerous others, is the quality of teaching at the school stage. However, the prerequisite and use of elementary education services in India have been improving quite fast during the last decade (Bajpai and Sachs, 2011; Govinda and Bandyopadhyay, 2008). However, the improvement of elementary education in India has not been consistent across the states and districts in India (Asadullah and Yalonetzky, 2010). The elementary education related interferences has been creating and improving admittance and infrastructure, investing in more teachers and their quality and several processes, aimed at improving educational outcomes. Teacher index, as indicators of educational development, gives more significance in adult literacy at tertiary level of schooling, include equipping the students with desirable skills, knowledge and attitudes that enable them to work and live in the society of knowledge (OECD, 2004). As vadivelu (2007) reported that teachers cause pleasing and likely revolution in the society wordlessly. However, teaching profession encourages and shapes the fortune of the nation in class rooms that may deemed as noblest profession in a society (Sharma and Dhaiya, 2012). From the point of view of an education system that is altering itself, it is imperative to look at not only the outcome indicators, but at the input and process indicators too.

There is actually general belief that teachers are very vital input to raise quality of education, the quality of teaching, has been considered as one of the vital parameters to study qualitative standards of education among states. For instance, UNESCO (2011) reported that a high pupil/teacher ratio can prevent teachers from knowing their pupils. The same issue of pupil/teacher ratio applies to primary school settings. Moreover, Afolabi (2002), while reporting on Ondo state, mentioned that the classrooms in most of the schools 
Appraisal of Teachers' Index in primary and upper primary level: a Geospatial Analysis

were inadequate in terms of decency, space, ventilation and insulation from heat, and thus the attendant result of non attainment of the set standards and goals in secondary schools.

Education at primary and upper primary level in Paschim Medinipur district is at a dialectical crossroad. There is an immense possibility of spreading the light of education to the remotest corners of the society that replicates the comparatively larger possibility, and space shaped for the marginalized communities to articulate their goals towards obtaining education by their children (Baksh and Munro, 2009). Alternatively, the growing class division in the field of primary education through the dependence on private tuition and private schooling (mainly because of the poor quality of education delivered in the primary schools) has led to the emergence of a threat before the public education system (Kumar, 2004). In the present study, we investigate the spatial disparity of learning environment on teaching at primary and upper primary level in Paschim Medinipur district, West Bengal (India).

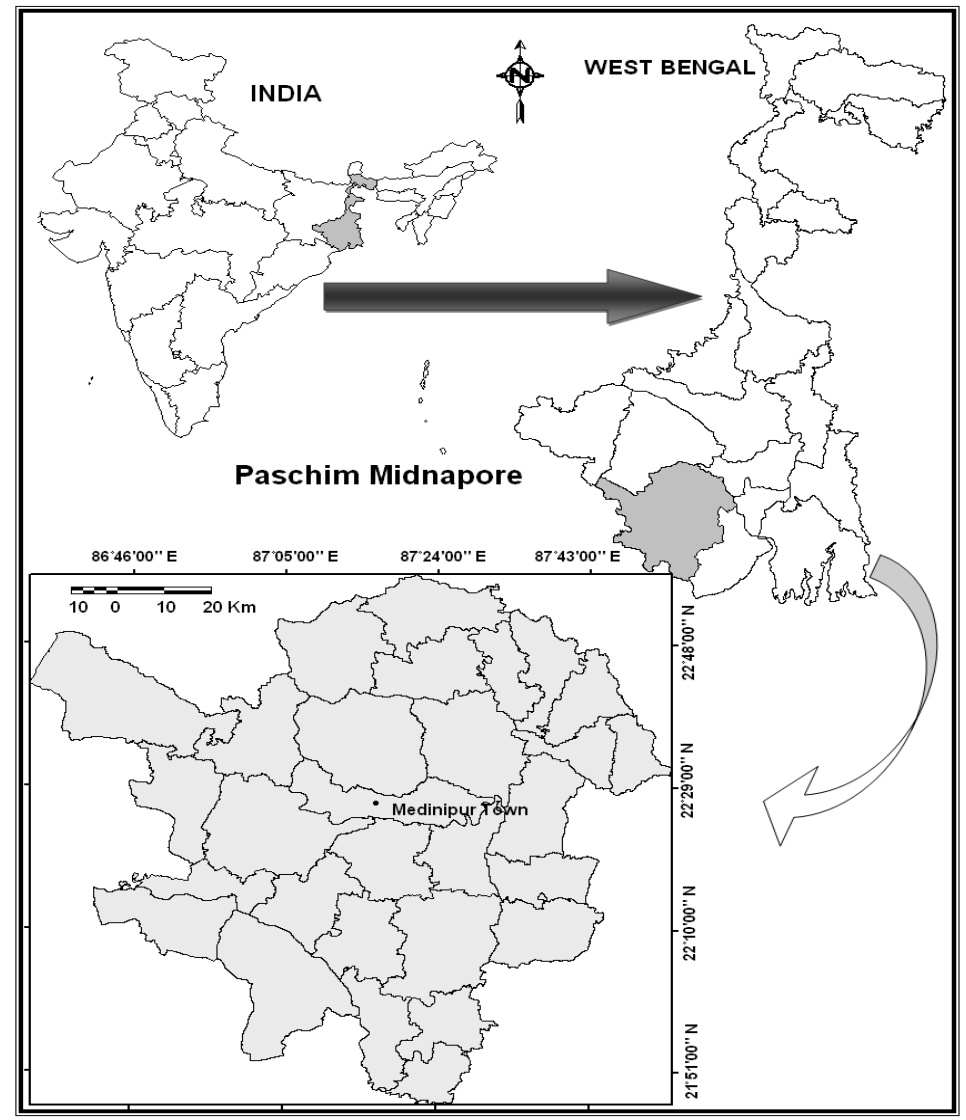

Figure 1: Location Map of the study area

Study area

\section{Materials and Methods}

The district Paschim Medinipur is situated in the south western side of West Bengal, extended between $21^{\circ} 47^{\prime} \mathrm{N}-23^{\circ} 00^{\prime} \mathrm{N}$ latitude and $86^{\circ} 40^{\prime} \mathrm{E}-87^{\circ} 52^{\prime} \mathrm{E}$ longitude (Figure 1). The total geographical area of the district is 9295.28 sq. $\mathrm{Km}$, and has a population of 5,943,300, with a population density of 636 inhabitants per square kilometre as per 2011 census (http://www.census2011.co.in/district.php). The district is primarily agricultural in nature, with cultivation being the chief livelihood of a majority of the people.

Data used

For the present study, block level data was collected from the District Information System for Education (DISE) for the year 2009 - 2010 from the District Project Office, Sarva Shiksha Mision (SSA), Medinipur, West Bengal. The data has been recorded from the 4,671 primary schools and 751 upper primary schools across the entire district.

Topographical sheets of the study area have been collected from the Survey of India (SOI), Kolkata West Bengal. The administrative boundary maps were collected from the District Land Revenue Office (DLRO), Medinipur, West Bengal. 


\section{Database generation}

Primarily, the SOI topographical maps were rectified through single image rectification system. The rectification has been done through Universal Transverse Mercator (UTM) projection system with World Geodetic System (WGS) 84 datum based on second order polynomial algorithm. The base maps (e.g., block and district boundary map) were rectified using topographical sheets.

\section{Creating GIS-based teacher's information analysis map}

The block wise information related to learning environment and teachings at primary and upper primary level have been arranged in a database in the Microsoft Office Access Programme. Afterwards, the data has been changed into the 'dbase' format and integrate into the GIS layer through the relational database system. ArcGIS software was used in transferring the elementary data into the base maps. Finally, based on the value, calculated through DISE data, a generalized score has been given to each parameter based on their importance on teaching learning environment. Finally, an index based score map was generated.

\section{Statistical analysis}

A descriptive characteristic of the study parameters was calculated. Spearman rank correlation (rho) co-efficient was used to estimate the relation between per cent of passed student and learning environment of teaching. All these analysis were calculated $<0.05$ significance level.

\section{Results and discussion}

The characteristics of learning environment of teaching of Paschim Medinipur district are described in Figure 3 at primary and upper primary level respectively. The descriptive characteristics of each parameter are represented in Table $1 \mathrm{a}$ and Table $1 \mathrm{~b}$.

Pupil-teacher ratio

Pupil-teacher ratio is one of the primary aspects to measure the educational quality. In general, teachers in the upper class can dedicate less time of each pupil compared to the lower class that may result of crowded classroom and make it difficult to concentrate on the study (Huebler, 2008). In Paschim Medinipur district, there were 342,684 numbers of school students and 11,783 numbers of primary teachers at Primary level. The average pupil-teacher ratio was 29.31within the entire district (Table 1a). The two most scatter points of this ratio were 23.08 (Gopiballavpur - I) and 35.43 (Keshpur) blocks. On the other hand, at the upper primary level 350,285 numbers of school students and 7,236 numbers of upper primary teachers were documented. The average pupilteacher ratio was 49.11 in our district (Table $1 \mathrm{~b}$ ). The two most disperse point of this ratio were 37.56 percent (Jamboni block) and 66.95 percent (Binpur - I) block.

Pupil-female teacher ratio

One of the targets of the Operation Blackboard scheme launched in 1987 was to make certain that at least one teacher in a school would rather be female (http://www.unicef.org/india/education_1551.htm). Over a period of time, the percentage of female teachers across school types has increased. In Paschim Medinipur district, all schools together have had 24.43 percent female teachers at primary level and 29.42 percent at upper primary level in 2009-2010. Block wise pupil-female teacher ration of Paschim Medinipur district is shown in Figure 2. However, the average percentage of pupil female teacher ratio was $136.30( \pm 32.18)$ at primary level in Paschim Medinipur district. At the upper primary level, the ratio was somewhat higher $(186.74 \pm 40.06)$.

Trained teacher

Teacher training has been identified as a crucial input for quality school education. Providing technical skills training to teachers in the elementary education are the key determining factor for improved student performance. In Paschim Medinipur district, at the primary level, the share of trained teacher to total teacher is 58.18 and upper primary level, the share of trained teacher to total teacher is 63.15 (Table 1a and 1b). However, the percent of trained teacher at the primary level is ranging from 47.17 percent (Medinpur block) to 77.49 percent (Sabong block). At the upper primary level, the highest value of trained teacher is recorded from Kharagpur - II block (72.65 percent), while the lowest value is recorded from the Nayagram (51.98 percent).

School-student ratio

Another important indicators of educational development is school-student ratio of each block that emphasis the balanced educational development of an area. The blocks in which less than 60 per cent of primary schools have school-student ratio are Gopiballavpur - I (53.02 percent), Gopiballavpur - II (54.90 percent), Jhargram (59.35 percent) and Sankril (51.42 percent). However, the average school-student ratio at primary level in the district was 82.96 per cent (Table 1a). At the upper primary level, the average school-student ratio was 535.71 percent. Moreover, the highest school-student ratio has been recorded from the Garhbeta - I block (722.41 percent), while lowest value was documented from the Chandrakona-I block (424.33). 


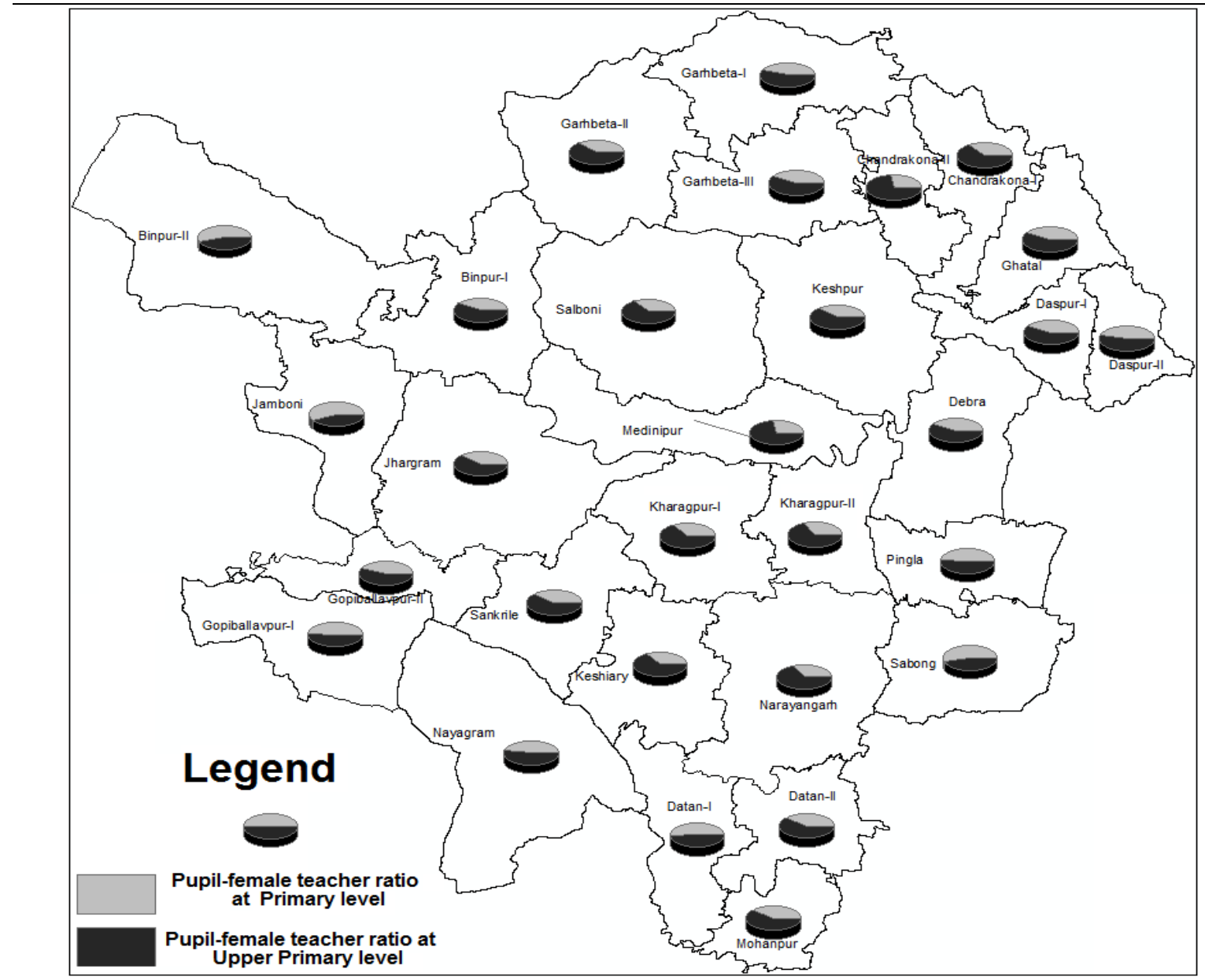

Figure 2: Pupil-female teacher ratio at the primary and upper primary level in Paschim Medinipur district. The highest percentage of female-pupil teacher ratio recoded block was Datan -I (208.95 percent), Gopiballavpur - I (187.73 percent), Jamoni (184.34 percent), and Garhbeta - I (175.62 percent) at the primary level. The corresponding percentage blocks at the upper primary level were Chandrakona -II (282.13 percent), Keshpur (234.37 percent) and Medinipur (233.1 percent).

Table 1a: Descriptive characteristics of block-wise teacher report at primary level in Paschim Medinipur district

\begin{tabular}{|c|c|c|c|c|c|c|c|c|}
\hline \multirow[b]{2}{*}{ Variables } & \multicolumn{2}{|c|}{$95 \% \mathrm{CI}$} & \multirow[b]{2}{*}{ Mean } & \multirow[b]{2}{*}{$\begin{array}{l}\text { Media } \\
\mathrm{n}\end{array}$} & \multirow{2}{*}{$\begin{array}{c}\text { Standar } \\
\text { d } \\
\text { deviatio } \\
n\end{array}$} & \multirow[b]{2}{*}{$\begin{array}{l}\text { Standar } \\
\text { d error }\end{array}$} & \multirow[b]{2}{*}{$\begin{array}{c}\text { Kurtosi } \\
\text { S }\end{array}$} & \multirow[b]{2}{*}{$\begin{array}{c}\text { Skewne } \\
\text { ss }\end{array}$} \\
\hline & $\underset{\mathrm{m}}{\text { Minimu }}$ & $\begin{array}{l}\text { Maximu } \\
\mathrm{m}\end{array}$ & & & & & & \\
\hline $\begin{array}{l}\text { Pupil-teacher } \\
\text { ratio }\end{array}$ & 21.62 & 37.00 & 29.31 & 29.41 & 3.92 & 0.64 & -0.71 & 0.09 \\
\hline $\begin{array}{l}\text { School-student } \\
\text { ratio }\end{array}$ & 51.41 & 149.42 & 82.96 & 79.53 & 21.10 & 3.46 & 1.52 & 0.93 \\
\hline $\begin{array}{l}\text { School-teacher } \\
\text { ratio }\end{array}$ & 2.06 & 4.20 & 2.80 & 2.74 & 0.43 & 0.07 & 1.79 & 0.96 \\
\hline $\begin{array}{c}\text { Classroom- } \\
\text { student ratio }\end{array}$ & 18.85 & 51.97 & 29.57 & 28.23 & 6.84 & 1.12 & 2.13 & 1.25 \\
\hline $\begin{array}{l}\text { School-classroom } \\
\text { ratio }\end{array}$ & 2.10 & 4.00 & 2.82 & 2.90 & 0.46 & 0.07 & -0.15 & 0.29 \\
\hline $\begin{array}{l}\text { Pupil-female } \\
\text { teacher ratio }\end{array}$ & 80.75 & 208.95 & $\begin{array}{c}136.3 \\
1 \\
\end{array}$ & $\begin{array}{c}129.0 \\
1 \\
\end{array}$ & 32.18 & 5.97 & 0.56 & 0.38 \\
\hline $\begin{array}{c}\% \text { of trained } \\
\text { teacher }\end{array}$ & 32.08 & 77.49 & 56.33 & 55.88 & 8.28 & 1.36 & 1.51 & -0.12 \\
\hline
\end{tabular}

$\mathrm{CI}=$ Confidence interval 


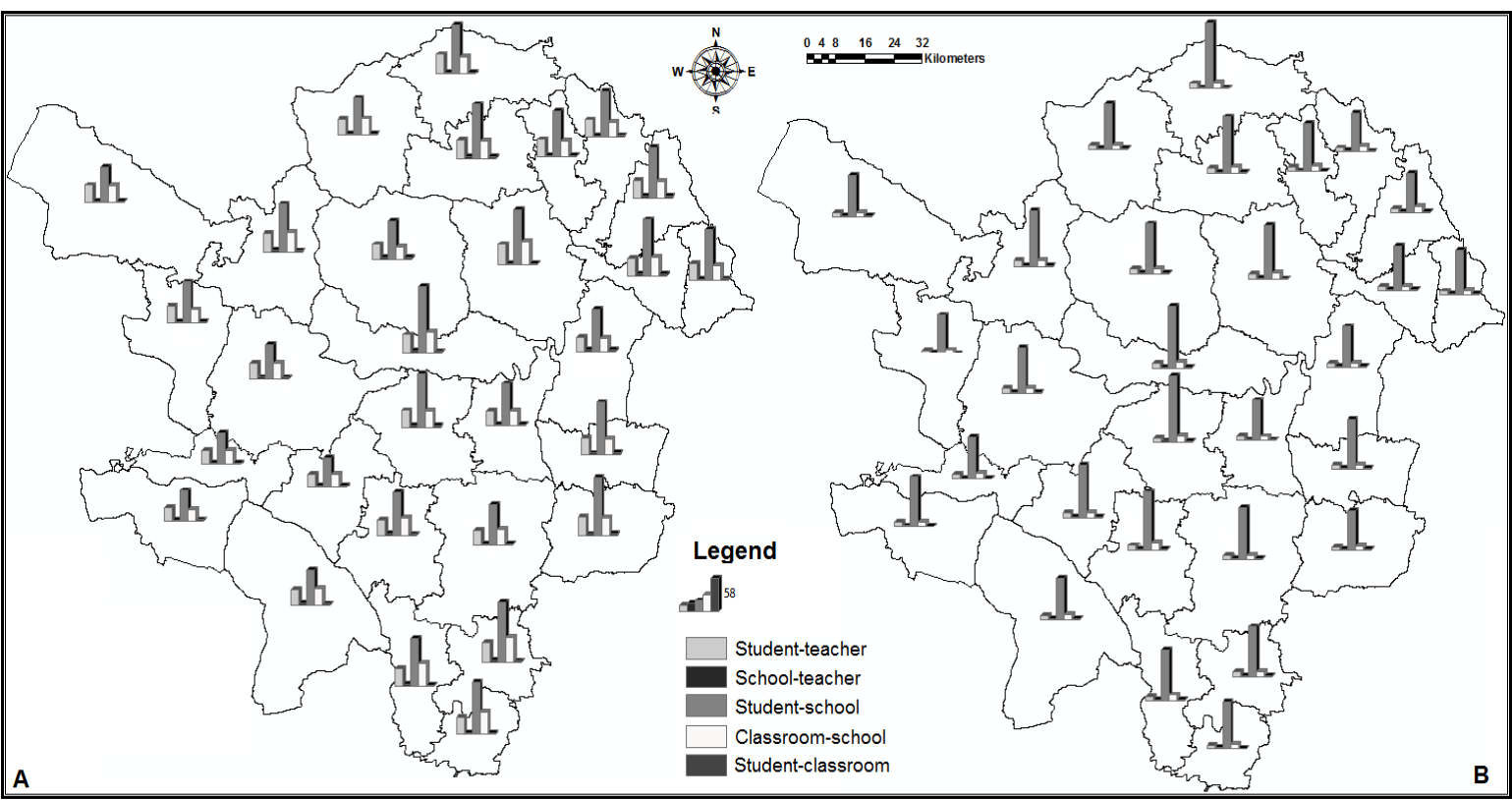

Figure 3: Block-wise learning environment ratio for teaching in Paschim Medinipur district. (A) Primary level and (B) Upper primary level.

\section{School-teacher ratio}

Employment of ample numbers of schools teachers is requirement for conveying quality of education. However, the school-teacher ratio (STR) for each block has been calculated separately, and the average value at primary level is 2.80. Nevertheless, the highest STR has been recorded from the Medinipur block (3.62), and the lowest was 2.07 for the Binpur-II block. Additionally, at the upper primary level the STR is higher, and the average STR is 10.99. The descriptive characteristics of STR at the upper primary level are shown in Table $1 \mathrm{~b}$.

\section{Classroom-student ratio}

The figure of classroom-student ratio (CSR) reveals the inadequacy of classrooms for elementary level of education. The crowded classrooms formulate difficult to concentrate on the study material and to learn. The results of overcrowding are lower academic achievement and increased dropout rates. The blocks that exceed the CSR of 30 are Binpur -I, Daspur-I, Dantan-I, Dantan-II, Keshiary, Keshpur, Medinipur, Mohanpur and Sabong.

Table 1b: Descriptive characteristics of block-wise teacher report at upper primary level in Paschim Medinipur district

\begin{tabular}{|c|c|c|c|c|c|c|c|c|}
\hline \multirow{2}{*}{ Variables } & \multicolumn{2}{|c|}{$95 \%$ CI } & \multirow{2}{*}{ Mean } & \multirow{2}{*}{ Median } & \multirow{2}{*}{$\begin{array}{l}\text { Standard } \\
\text { deviation }\end{array}$} & \multirow{2}{*}{$\begin{array}{l}\text { Standard } \\
\text { error }\end{array}$} & \multirow{2}{*}{ Kurtosis } & \multirow{2}{*}{ Skewness } \\
\hline & Minimum & Maximum & & & & & & \\
\hline $\begin{array}{l}\text { Pupil-teacher } \\
\text { ratio }\end{array}$ & 35.25 & 68.31 & 49.11 & 49.03 & 7.93 & 1.30 & 0.16 & 0.57 \\
\hline $\begin{array}{l}\text { School-student } \\
\text { ratio }\end{array}$ & 424.33 & 728.5 & 535.71 & 529.00 & 88.35 & 14.52 & -0.52 & 0.63 \\
\hline $\begin{array}{l}\text { School-teacher } \\
\text { ratio }\end{array}$ & 8.00 & 15.3 & 10.99 & 10.75 & 1.48 & 0.24 & 1.18 & 0.72 \\
\hline $\begin{array}{l}\text { Classroom- } \\
\text { student ratio }\end{array}$ & 27.27 & 80.76 & 56.03 & 54.18 & 11.87 & 1.95 & -0.30 & -0.07 \\
\hline $\begin{array}{c}\text { School- } \\
\text { classroom ratio }\end{array}$ & 6.82 & 17.81 & 9.85 & 9.68 & 2.11 & 0.35 & 5.23 & 1.75 \\
\hline $\begin{array}{l}\text { Pupil-female } \\
\text { teacher ratio }\end{array}$ & 120.97 & 282.13 & 186.74 & 190.33 & 40.06 & 7.44 & -0.55 & 0.18 \\
\hline $\begin{array}{c}\% \text { of trained } \\
\text { teacher }\end{array}$ & 48.15 & 78.84 & 64.40 & 64.14 & 6.68 & 1.09 & 0.59 & 0.19 \\
\hline
\end{tabular}

$\mathrm{CI}=$ Confidence interval 
School-classroom ratio

The availability and condition of classroom reveal an important parameter for improvement of elementary education. At the primary level, the average school-classroom ratio (SCR) is 2.82 , with the highest value documented from the Pingla block (3.39). At the upper primary level, the average SCR is 9.85 (Table 1b). The SCR is ranging from 6.82 - 12.66. In Daspur - I, Daspur - II, Debra, Garhbeta -I, Garhbeta - II, Gopiballavpur - I, Kharagpur - I, Narayangarh, Pingla, Salboni and Sankrile SCR ratio is more than 10 per cent.

Correlation between teaching environment and per cent of student passed at primary level

A Spearman rank correlation coefficient $(r h o)$ analysis was calculated between the per cent of student passed at each block and the parameters related to teaching environment. The results of school-teacher ratio (rho - 0.52), school-student ratio (rho - 0.44), school-classroom ratio (rho - 0.60) showed positive and significant relationship with the average per cent of passed student. Furthermore, a correlation was also measured between the teaching learning parameters and the above 60 per cent passed student at primary level. Our results showed strong and positive relationship with the school-teacher ratio ( $r h o-0.50)$, school-student ratio (rho - 0.44), school-classroom ratio ( $r h o-0.37)$ and per cent of trained teacher $(r h o-0.38)$. Additionally, a significant and negative relationship was found between the pupil-female teacher ratio and average percent of passed student (Table 2). Alternatively, a meagre relationship was found with the student-teacher and classroom-student with the per cent of passed student. The results also illustrated a positive and significant relationship between the per cent of trained teacher and the above 60 per cent passed student of the study site (rho - 0.38); while, insignificant relationship was established with the average per cent of passed student.

Table 2: Calculation of Spearman rank correlation coefficient ( $r h o$ ) between passed per cent of student and teaching environmental parameters at primary level and upper primary level

\begin{tabular}{|c|c|c|c|c|}
\hline \multirow{2}{*}{ Variables } & \multicolumn{2}{|c|}{ Average per cent of passed } & \multicolumn{2}{|c|}{ Passed above 60 per cent } \\
\hline & rho & $P$-value & rho & $P$-valuc \\
\hline \multicolumn{5}{|c|}{ Primary level } \\
\hline Student-teacher & 0.16 & 0.40 & 0.19 & 0.32 \\
\hline School-teacher & 0.52 & 0.005 & 0.50 & 0.007 \\
\hline School-student & 0.44 & 0.02 & 0.44 & 0.02 \\
\hline Classroom-student & -0.04 & 0.81 & 0.17 & 0.37 \\
\hline School-classroom & 0.60 & 0.001 & 0.37 & 0.04 \\
\hline $\begin{array}{l}\text { Pupil-female teacher } \\
\text { ratio }\end{array}$ & -0.39 & 0.02 & -0.09 & 0.57 \\
\hline$\%$ trained teacher & 0.18 & 0.34 & 0.38 & 0.05 \\
\hline \multicolumn{5}{|c|}{ Upper Primary level } \\
\hline Student-teacher & 0.04 & 0.76 & 0.03 & 0.88 \\
\hline School-teacher & -0.13 & 0.49 & 0.01 & 0.95 \\
\hline School-student & -0.13 & 0.49 & -0.04 & 0.83 \\
\hline Classroom-student & -0.14 & 0.46 & -0.15 & 0.42 \\
\hline School-classroom & 0.21 & 0.26 & 0.27 & 0.17 \\
\hline $\begin{array}{l}\text { Pupil-female teacher } \\
\text { ratio }\end{array}$ & -0.11 & 0.25 & -0.16 & 0.20 \\
\hline$\%$ trained teacher & 0.35 & 0.06 & 0.37 & 0.05 \\
\hline
\end{tabular}

$r h o=$ Spearman rank correlation

At the upper primary level, no any significant relationship was established with the teaching environmental parameters and per cent of student passed in Paschim Medinipur district. Only a significant relationship was developed with the between the per cent of trained teacher and the above 60 per cent passed student of the study site ( $r h o-0.37, p<0.05)$.

\section{Teacher index-based score}

Based on the teaching learning parameters, a teacher's index map was delineated at both the primary and upper primary level (Figure 4). Determination of weightage of each parameter the most decisive in integrated analysis, as the output is largely dependent on the assignment of proper weightage. In this analysis, weightage has been given based on the importance of correlation value at the primary and upper primary level, represented in the table 2. However, the results show that Paschim Medinipur records inequality of teaching learning environment opportunity by considerable variation across the blocks and district. Based on the index value the blocks are classified into 4 categories using geometric interval in ArcGIS software as, 'low', 'medium', 'good' and 'very good' teaching learning environmental parameters. However, blocks of the eastern part of the district are attaining highest facility compare to the western part at both the primary and upper 
primary level. The blocks of northern part are conquering low to medium facility. Moreover, at primary level, the blocks of central part of the district have the good facilities of teaching learning environment, whereas, medium facilities are available at the upper primary level.

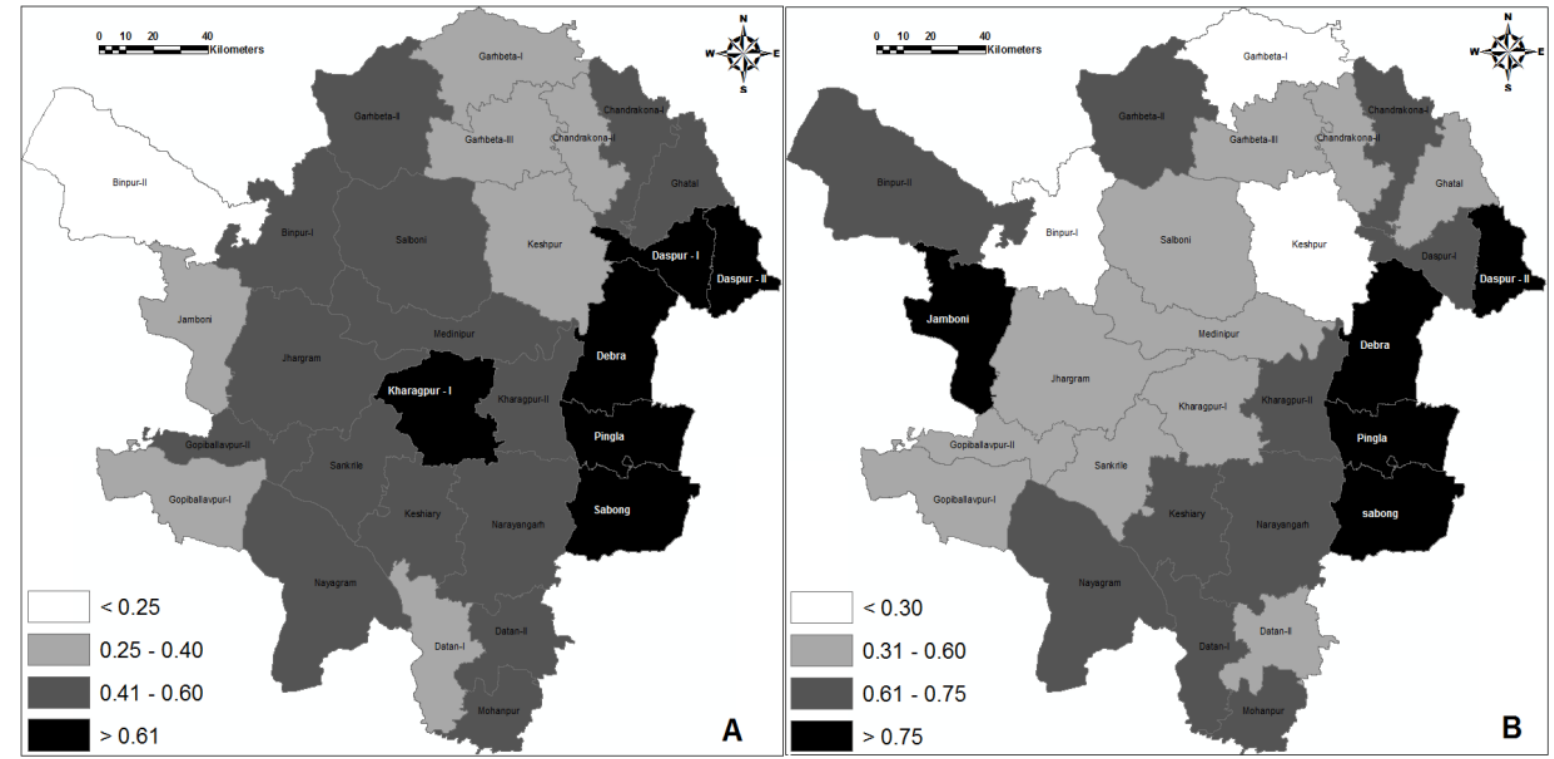

Figure 4: Teacher index map of Paschim Medinipur district. Figure shows (A) Primary level, (B) Upper primary level.

\section{Conclusion}

The district Paschim Medinipur stands out as the higher inequality in terms of teaching learning environment at both the primary and upper primary level. These efforts on the part of pioneering teachers are to be acclaimed - they have helped to demonstrate that powerful analytic tools can be made accessible to students. However, the present analysis may aids to compare the current trajectory of GIS integration with the rise and fall of previous technologies. GIS as a tool can be a natural fit in these more substantive learning environments, which is a productive step forward in that is needed much more to splice an alien technology into an existing program. In general, the western and northern blocks experienced lower inequality when compare to the eastern blocks of the district. Our findings also illustrated that significant positive association between school-teacher ratio, school-student ratio, and school-classroom ratio with the average per cent of passed student and the above 60 per cent passed student at primary level. Furthermore, the result of our analysis also showed negative relationship between the pupil-female teacher ratio and the percent of passed student at both the primary and upper primary level. However, at the upper primary level, only a significant relationship was developed with the per cent of trained teacher and successful students. The results of our analysis illustrated some significant result by delineating the current situation of elementary education due to the Sarva Shiksha Abhiyan (SSA) that may help to mark out the improvement in school participation. For attaining universalisation of elementary education system, the centre and state governments have started numerous processes, which have resulted in escalating the preservation rate of students; hence the quality of education at the elementary level could be expected to go up. Finally, it will be interesting to follow up this study using more recent data in the near future to reduce the inequality of teaching learning parameters across the district. An enhanced teaching learning ambience in the school and an amplify in the eminence of education would absolutely draw more students to schools and also amplify the maintenance rates. Moreover, attention needs to be given to circumstance factors such as infrastructure facilities of school, accessibility that affect schooling directly and are common across some social groups.

\section{Acknowledgement}

We are very much thankful to Mr. Soumen Duary, Office of the SSA, Paschim Medinipur District, West Bengal for freely providing the data. We are also thankful to the GIS laboratory of Vidyasagar University, Medinipur, West Bengal, India for providing space to do the work. 


\section{References}

[1] Afolabi, F. O. (2002). The school building and its environment. Implication on the achievement of functional Universal Basic Education programme in Ondo State. In T. Ajayi, J. O. Fadipe, P. K. Ojedele, \& E. E. Oluchukwu (Eds.), Planning and Administration of Universal Basic Education in Nigeria (pp. 101-110). Ondo: National Institute for Educational Administration and Planning (NIEPA).

[2] Alexander R, (2008). Education for all, the quality imperative and the problem of Pedagogy. Consortium for Research on Educational Access, Transitions and Equity. Create Pathways To Access, Research Monograph No 20.InstituteofEducation,UniversityofLondon.Available at: http://www.create-rpc.org/pdf_documents/PTA20.pdf

[3] Asadullah MN, Yalonetzky G, (2010). Inequality of Educational Opportunity in India: Changes over Time and across States. IZA DP No. 5146; P.O. Box 724053072 Bonn, Germany. Available at: http://ftp.iza.org/dp5146.pdf

[4] Bajpai N and Sachs JD, (2011). India's decade of development: looking back at the last 10 years and looking forward to the next 20. CGC | SA Working Paper No. 3. Columbia Global Centers | South Asia, Columbia University Express Towers 11th Floor, Nariman Point, Mumbai 400021Available at: http://www.globalcenters.columbia.edu/southasia/

[5] Baksh R, Munro T, 2009. Learning to live together: using distance education for community peace building. ISBN 978-1-89497535-3. Commonwealth of Learning, Vancouver, 2009, 1055 West Hastings, Suite 1200, Vancouver, British Columbia, Canada V6E 2E9. Available at: http://creativecommons.org/licenses/by-sa/3.0

[6] Desai S, Kulkarni V (2008). Changing Educational Inequalities in India in the Context of Affirmative Action. Demography. 2008 May; 45(2): 245-270.

[7] Govinda R, Bandyopadhyay M, 2008. Access to Elementary Education in India-Country Analytical Review. Consortium for Research on Educational Access, Transitions and Equity. National University of Educational Planning and Administration, NUEPA. Available at: http://www.create-rpc.org/pdf_documents/India_CAR.pdf

[8] Huebler F (2008). Occupation: Analysis of international education data. Available at: http://huebler.blogspot.in/2008/10/ptr.html

[9] Kumar Rana. The Possibilities of Mid-day Meal Programme in West Bengal. Workshop on "West Bengal: Challenges and Choices", organized by the Centre for Social Sciences, Calcutta, on 27 and 28 July 2004 . Available at: http://sccommissioners.org/News/Documents/ -middaymealprogrammeinwestbengal.pdf

[10] Nordic Recognition Information Centres (NRIC), 2006. The system of education in India. Available at: www.norric.org

[11] Organisation for Economic Co-operation and Development (OECD), 2004. Raising the quality of educational performance at school. Available at:

[12] http://www.oecd.org/edu/29472036.pdf

[13] Sharma S, Dhaiya P, 2012. Comparative Study of Attitude towards Teaching of Science and Arts of B.Ed. Students. Bhartiyam International Journal of Education \& Research, 1(2): 85-110.

[14] UNESCO (2011). Education for All Global Monitoring Report 2011. The hidden crisis: Armed conflict and education. Paris: UNESCO.

[15] Vadivelu VM, 2007. Education System and Teacher Training in India. Ethiop. J.Educ \& Sc., $3(1): 97$ - 102.

[16] Ward M (2007). Rural Education: India Infrastructure Report 2007. Pp. 286-317. Available at: http://www.dise.in/Downloads/Use\%20of\%20Dise\%20Data/Michael\%20ward.pdf 